\title{
X-Ray Diffraction and Infrared Study of the 'Sulphur Granules' of Actinomyces bovis
}

\author{
By P. D. FRAZIER AND B. O. FOWLER \\ Laboratory of Histology and Pathology, National Institute of Dental \\ Research, National Institutes of Health, Bethesda, Maryland 20014, U.S.A.
}

(Accepted for publication 21 October 1966)

SUMMARY

Bovine actinomycosis exudate was studied to determine the chemical composition and mineral phase(s) of the so-called 'sulphur granules'. The major constituents, $\mathrm{CaO}$ and $\mathrm{P}_{2} \mathrm{O}_{5}$, accounted for $86-89 \%$ of the ashed granules. The granules also contained $\mathrm{Na}, \mathrm{K}, \mathrm{Mg}$ (as oxides) and $\mathrm{Cl}$ which added up to $10-14 \%$. Although the X-ray diffraction patterns indicated only poorly formed apatite; the infrared spectrum could be interpreted as arising from poorly crystallized apatite and/or a partially dehydrated or hydrolysed octacalcium phosphate either or both mixed with anhydrous dicalcium phosphate. The formation of pyrophosphate $(44.5 \%)$ in the ignited granules indicated the presence of considerable acid phosphate in the original material.

\section{INTRODUCTION}

Because of similarities in the morphology of the organisms and pathological descriptions of actinomycosis (lumpy jaw) in cattle and cervico-facial actinomycosis in man, it was considered for many years that the organisms causing these diseases were the same. Recently, morphological, physiological and biochemical studies (Erikson, 1940; Thompson, 1950; Pine, Howell \& Watson, 1960) indicated that the animal disease is caused by Actinomyces bovis and the human infections are caused by A. israelii, A. naeslundi (Thompson \& Lovestedt, 1951; Howell, Murphy, Paul \& Stephan, 1959) and Norcardia asteroides (Burnett \& Scherp, 1957).

Although small differences have been found between the animal and human strains, so-called 'sulphur granules' are invariably present in the clinical infection. They can be observed and easily isolated from the draining sinuses; their presence is regarded as a valuable aid in the diagnosis of the disease. The granule is generally a yellowish, hard, spherical body containing a peripheral arrangement of 'clubs' which can be seen upon microscopic examination (Pine et al. 1960).

There has been considerable speculation concerning the structure of the granule and the clubs surrounding it. Recent studies (Pine \& Overman, 1963) indicated that the granule formed by Actinomyces bovis is a mycelial mass cemented together by a polysaccharide + protein complex probably excreted by the organism. The centre of the mass is calcium phosphate according to Pine \& Overman (1963), but the mineral phase(s) have not been identified.

Viable Actinomyces israelii, A. naeslundi and other bacterial species become mineralized, i.e. form apatite when implanted in dialysis bags in the peritoneal cavity of rats (Rizzo, Martin, Scott \& Mergenhagen, 1962). The mineral is found intra- and extra- 
cellularly, but granules were not observed (Rizzo, Scott \& Bladen, 1963). Formation of 'sulphur granules' seems to require the local conditions associated with the chronic infection, because they have been observed only once in vitro (Wright, 1905). Our study, therefore, was undertaken to determine the chemical composition and to characterize the mineral phase(s) of the granules.

\section{METHODS}

The 'sulphur granules' used for this study were obtained from bovine actinomycosis exudates. Sample 1 (from the National Animal Disease Laboratory, Ames, Iowa) consisted of a pooled exudate fixed in an aqueous solution of $10 \%(\mathrm{v} / \mathrm{v})$ glycerol and $2 \%$ formalin. Sample 2 was removed directly from an infected steer. The identity of the micro-organisms from sample 1 was established by culture and microscopic examination. Sample 2 was considered to be an actinomycosis exudate on the basis of the clinical infection and the morphology of the granules.

Initially, both samples were washed with water at about $40^{\circ}$ for $8 \mathrm{hr}$, centrifuged and dried at $40^{\circ}$ in vacuum. To decrease the organic component of the exudate, a portion of sample 1 was ashed by the low-temperature incineration method for ashing microorganisms described by Thomas (1964). Extraction with organic solvents or strong base was avoided because of the increased possibility of introducing changes in the inorganic phase(s). Portions of the washed and low-temperature incinerated granules from sample 1 were ignited at $400^{\circ}(50 \mathrm{hr}) 500^{\circ}(24 \mathrm{hr})$ and $900^{\circ}(12 \mathrm{hr})$. Sample 2 was ashed directly at $650^{\circ}$ and $900^{\circ}$.

$\mathrm{X}$-ray diffraction and infrared analyses were done on the original water-washed and ashed granules. Diffraction patterns were recorded in a Debye-Scherrer type powder camera (114.59 mm. diameter) using Ni-filtered $\mathrm{Cu}$ radiation. Exposure time at $45 \mathrm{kV}$ and $35 \mathrm{~mA}$ was $6 \mathrm{hr}$. Infrared spectra of the samples in $\mathrm{KBr}$ pellets were obtained utilizing a double-beam spectrophotometer covering the range $4000-200 \mathrm{~cm}^{-1}$.

Portions of the water-washed granules were ashed (sample 1 at $500^{\circ}$ and sample 2 at $650^{\circ}$ ) and subsequently analysed for $\mathrm{Ca}, \mathrm{P}, \mathrm{Na}, \mathrm{K}, \mathrm{Mg}, \mathrm{Cl}$ and trace elements. In addition, samples of the low-temperature incinerated portion of sample 1, ignited at $400^{\circ}$ and $500^{\circ}$, were analysed for orthophosphate and pyrophosphate. The $\mathrm{CO}_{2}$ content was estimated from infrared spectra.

\section{RESULTS}

\section{Chemical analyses}

Chemical analyses of the ashed samples for selected constituents are given in Table 1. The major constituents $\mathrm{Ca}$ and $\mathrm{P}$, calculated as the oxides, account for $89 \%$ of sample 1 and $86 \%$ of sample 2 . Except for $\mathrm{CO}_{3}$, infrared active anions other than ortho- and pyrophosphate were not evident from the infrared spectra of the ashed samples. The $\mathrm{Na}, \mathrm{K}, \mathrm{Mg}$ (as oxides) and $\mathrm{Cl}$ percentages totaled accounted for $10 \%$ of sample 1 and $14 \%$ of sample 2 . Approximately $1 \%$ of ashed sample 1 was estimated to be carbonate. The Ca:P molar ratios for ashed samples 1 and 2 were 1.45 and 1.21 respectively. The $\mathrm{Ca}: \mathrm{P}$ molar ratio for sample 1 compares favourably with the $1 \cdot 40$ ratio calculated from the data presented by Pine \& Overman (1963). Their ash value was much higher $(56.0 \%$ compared to $12.0 \%$ ) apparently caused by the removal of 
pus and organic debris by extracting the granules with strong base (Dr L. Pine, personal communication). The low-temperature incinerated granules ignited at $400^{\circ}$ and $500^{\circ}$ yielded 40.6 and $44.5 \%$ of the phosphorus as pyrophosphate, respectively.

Table 1. Analyses of ashed sulphur granules

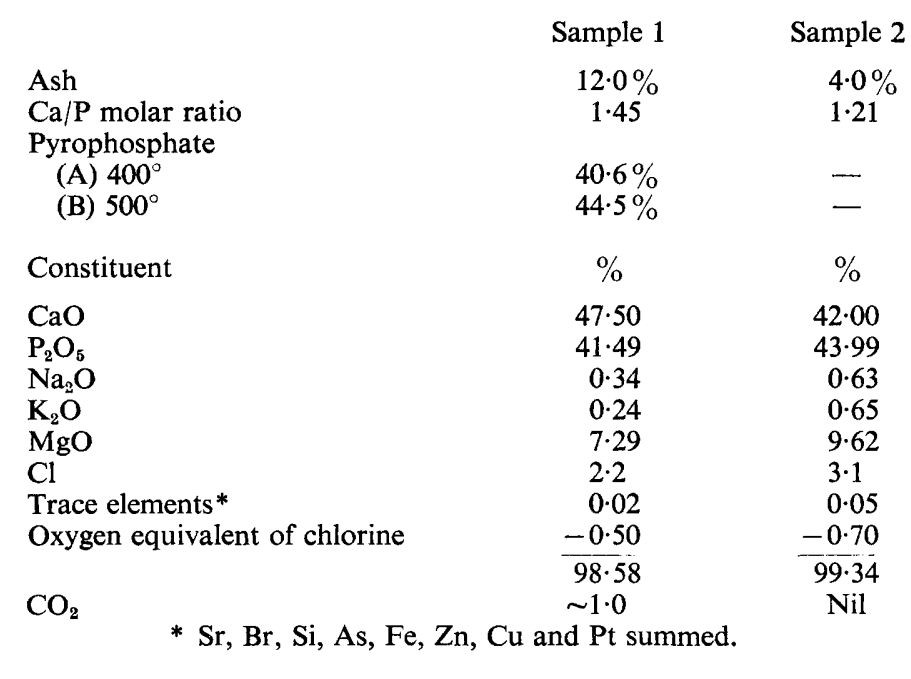

\section{$X$-ray and infrared analyses of original and low-temperature incinerated granules}

The X-ray diffraction patterns of the washed and non-washed granules were characteristic of poorly crystallized apatite. The diffraction lines were weaker and more diffuse than those observed for normal bone (ASTM publication, 1960; Carlström \& Engström, 1956; Posner, Eanes, Harper \& Zipkin, 1963; Frazier, Zipkin \& Mills, 1967). The diffraction pattern of the low-temperature incinerated granules remained indistinguishable from poorly crystallized apatite; the primary difference in the diffraction pattern as compared with that of the original was a decrease in background (P. D. Frazier, F. J. Brown, L. S. Rose \& B. O. Fowler, in preparation).

Interpretation of the infrared spectra of the original 'sulphur granules', with regard to the inorganic phase, was hindered by the organic component $(\sim 90 \%)$, although poorly defined bands were observed in the proper frequency ranges for apatite.

The infrared spectrum of the inorganic component(s) of the low-temperature incinerated granules consisted of better resolved $\nu_{3}, \nu_{1}, \nu_{4}$ and $\nu_{2}$ bands of apatite. In addition, the $\mathrm{OH}$ stretching band of hydroxyapatite $\left(\mathrm{Ca}_{10}\left(\mathrm{PO}_{4}\right)_{6}(\mathrm{OH})_{2}\right)$ was observed at $3570 \mathrm{~cm} \cdot .^{-1}$, but was very weak, and the $\mathrm{OH}$ librational mode at $631 \mathrm{~cm} .^{-1}$ was barely detectable (Fowler, Moreno \& Brown, 1966). A broad shoulder from about 930 to $850 \mathrm{~cm} .^{-1}$ was present. This band could partially arise from anhydrous dicalcium phosphate $\left(\mathrm{CaHPO}_{4}\right)$ which has an absorption band at $892 \mathrm{~cm} .^{-1}$ (Fowler et al. 1966). Also, octacalcium phosphate $\left(\mathrm{Ca}_{8} \mathrm{H}_{2}\left(\mathrm{PO}_{4}\right)_{6} .5 \mathrm{H}_{2} \mathrm{O}\right)$ has weak absorption bands in this region at 910 and $865 \mathrm{~cm} .^{-1}$ which after partial dehydration, either by heating to 150-200 (Fowler et al. 1966) or by hydrolysis (B. O. Fowler, unpublished data) results in a shoulder at about $875-865 \mathrm{~cm} .^{-1}$. In general, the spectrum could be inter- 
preted as arising from a poorly crystallized hydroxyapatite and/or a partially dehydrated or hydrolysed octacalcium phosphate, either or both mixed with anhydrous dicalcium phosphate.

\section{$X$-ray and infrared analyses of ignited granules}

The X-ray and infrared patterns of the low-temperature ashed and non-ashed granules ignited at $400^{\circ}$ for $50 \mathrm{hr}$ showed poorly crystallized apatite; in addition, the infrared spectrum contained pyrophosphate bands. After continued ignition of the original granules at $400^{\circ}$ for 3 weeks, both apatite and $\gamma-\mathrm{Ca}_{2} \mathrm{P}_{2} \mathrm{O}_{7}$ were detected from the $\mathrm{X}$-ray and infrared patterns. Further ignition of the low-temperature incinerated portion of sample 1 at $500^{\circ}$ for $24 \mathrm{hr}$ resulted in the formation of $\beta-\mathrm{Ca}_{2} \mathrm{P}_{2} \mathrm{O}_{7}$ along with the apatite.

Relative intensities indicated additional X-ray diffraction lines nearly superimposed on the 2.88 and $3.21 \AA$ lines of $\beta-\mathrm{Ca}_{2} \mathrm{P}_{2} \mathrm{O}_{7}$ and the $2.63 \AA$ line of apatite. These lines could arise from $\beta-\mathrm{Ca}_{3}\left(\mathrm{PO}_{4}\right)_{2}$ or a magnesium substituted $\beta$-tricalcium phosphate ( $\mathrm{Mg}$ content of this sample $4.4 \%$ ) which have been shown to form at temperatures as low as $100^{\circ}$ in the presence of magnesium (Trautz, Fessenden \& Newton, 1954). The portion of ashed sample 1 pre-ignited in the low-temperature incinerator gave an infrared pattern with better resolved pyrophosphate bands as compared with the portion of ashed sample 1 which was not pre-ignited in the low-temperature incinerator. The effects of prior removal of the organic fraction, by this technique, on recrystallization and/or pyrophosphate formation on ignition are at present under investigation.

Sample 2, which was ignited at $650^{\circ}$ for $24 \mathrm{hr}$, formed $\alpha-\mathrm{Ca}_{2} \mathrm{P}_{2} \mathrm{O}_{7}$ and $\beta-\mathrm{Ca}_{3}\left(\mathrm{PO}_{4}\right)_{2}$; the $\alpha-\mathrm{Ca}_{2} \mathrm{P}_{2} \mathrm{O}_{7}$ converted to $\beta-\mathrm{Ca}_{2} \mathrm{P}_{2} \mathrm{O}_{7}$ after ignition at $900^{\circ}$ for $12 \mathrm{hr}$. The phase transition from $\beta$ - to $\alpha-\mathrm{Ca}_{2} \mathrm{P}_{2} \mathrm{O}_{7}$ is reported as $1140^{\circ}$ (Hill, Faust \& Reynolds, 1944). Formation of $\alpha-\mathrm{Ca}_{2} \mathrm{P}_{2} \mathrm{O}_{7}$ below the reported phase transition temperature $\left(1140^{\circ}\right)$ in apatitic calcium phosphates (ignited at $600^{\circ}$ ) has been reported by Rowles (1964). Sample 1 formed, as expected, $\beta-\mathrm{Ca}_{2} \mathrm{P}_{2} \mathrm{O}_{7}$ and $\beta-\mathrm{Ca}_{3}\left(\mathrm{PO}_{4}\right)_{2}$ on ignition at $900^{\circ}$.

\section{DISCUSSION}

Several investigators have used the formation of pyrophosphate in pyrolysed synthetic calcium phosphates as an index of the presence of acid phosphate in the original material (Gee \& Deitz, 1955; Winand, 1961; Herman, Francois \& Fabry, 1961 ; Kühl \& Nebergall, 1963; Fowler et al. 1966). The pyrophosphate formation in mineralized tissues, upon ignition, has also served as an indication of the presence of acid phosphate in the original material (Herman \& Dallemagne, 1961; Francois \& Herman, 1961; Dallemagne, 1964).

The low-temperature ashed 'sulphur granules' ignited at 400 and $500^{\circ}$ yielded 40.6 and $44.5 \%$ of the phosphorus as pyrophosphate, respectively. These values may not represent maximum conversion because insufficient sample was available to determine the percentages formed with different temperatures and duration of heating. Studies of pyrolyzed synthetic calcium phosphates by Herman et al. (1961) and Fowler et al. (1966) showed maximum pyrophosphate formation at about $500^{\circ}$.

Probable sources of formation of this pyrophosphate could be $\mathrm{CaHPO}_{4}(\mathrm{Gee} \&$ Deitz, 1955), octacalcium phosphate (Brown, Smith, Lehr \& Frazier, 1962), and 
'tricalcium phosphate hydrate' (Dallemagne, 1964; Herman \& Dallemagne, 1961; Francois \& Herman, 1961). According to the reactions given by Gee \& Deitz (1955) a mixture of hydroxyapatite and $\mathrm{CaHPO}_{4}$ with the $\mathrm{Ca}: \mathrm{P}$ molar ratio of our sample $(1.45)$ would be expected to yield $32.3 \%$ pyrophosphate; according to Brown et al. (1962) a mixture of octacalcium phosphate and hydroxyapatite would also produce $32 \cdot 3 \%$ pyrophosphate.

The percentage of pyrophosphate formed on pyrolysis is well above that predicted on the basis of the two-component model systems listed above; it is also above that predicted assuming, for example, a three-component system containing various proportions of octacalcium phosphate, anhydrous dicalcium phosphate and hydroxyapatite to make a net $\mathrm{Ca}: \mathrm{P}$ molar ratio of $1 \cdot 45$. However, the actual $\mathrm{Ca}: \mathrm{P}$ molar ratio of the $\mathrm{CaO} \cdot \mathrm{P}_{2} \mathrm{O}_{5} \cdot \mathrm{H}_{2} \mathrm{O}$ phases could be less than 1.45 due to the presence of a calcium compound(s) other than phosphate which escaped detection by our methods.

In conclusion, the chemical analyses showed that the inorganic constituents of the 'sulphur granules' examined consisted primarily of calcium phosphate which is in agreement with the work of Pine \& Overman (1963). The X-ray and infrared patterns were not sufficiently descriptive to unequivocally identify the calcium phosphate phase(s). The X-ray pattern of the granules indicated poorly crystalized apatite; the infrared spectrum could be interpreted as arising from a poorly crystalized hydroxyapatite and/or a partially dehydrated or hydrolysed octacalcium phosphate, either or both mixed with anhydrous dicalcium phosphate. The formation of $44.5 \%$ pyrophosphate in the ignited granules indicated the presence of considerable acid phosphate in the original granules; both octacalcium phosphate and anhydrous dicalcium phosphate are probable sources of the pyrophosphate formed on ignition.

The authors wish to acknowledge Dr A.C. Pier (National Animal Disease Laboratory, Ames, Iowa) for supplying sample 1 of the actinomycosis exudate and thank Dr I. Zipkin (National Institute of Dental Research), Dr W. C. Alford (National Institute of Arthritis and Metabolic Diseases), Mrs B. M. Wallace and $\mathrm{Mr} \mathrm{H}$. McDowell (American Dental Association Research Division, National Bureau of Standards) and the Union Carbide Corporation (Oak Ridge, Tennessee) for the chemical analyses.

\section{REFERENCES}

ASTM publication 48-J, X-Ray Powder Data File (1960). Philadelphia; American Society for Testing Materials.

Brown, W. E., Smith, J. P., Lehr, J. R. \& Frazier, A. W. (1962). Crystallographic and chemical reactions between octacalcium phosphate and hydroxyapatite. Nature, Lond. 196, 1050.

Burnet, G. W. \& SCherp, H. W. (1957). Oral Micro-Biology and Infectious Disease. Baltimore: The Williams and Wilkins Co.

CARlström, D. \& EngSTRöM, A. (1956). Ultrastructure and distribution of mineral salt in bone tissue. The Biochemistry and Physiology of Bone. Ed. by G. H. Bourne, p. 149. New York: Academic Press, Inc.

Dallemagne, M. J. (1964). Phosphate and carbonate in bone and teeth. Proc. 1st European Bone and Tooth Symposium. Ed by H. J. J. Blackwood. Oxford: Pergamon.

Erikson, D. (1940). Pathogenic anerobic organisms of the Actinomyces group. Spec. Rep. Ser. med. Res. Coun., Lond. no. 240.

Fowler, B. O., Moreno, E. C. \& Brown, W. E. (1966). Infra-red spectra of hydroxyapatite, octacalcium phosphate and pyrolysed octacalcium phosphate. Arch. Ora. Biol. 11, 477

Francois, P. \& Herman, H. (1961). Le composé minéral fondamental des tissus calcifiés. II. Les sels osseux contiennent un phosphate de calcium differént de l'hydroxylapatite. Bull. Soc. Chim. Biol. 43, 643 . 
FraZIER, P. D., ZIPKIN, I. \& MilLs, L. F. (1967). X-ray diffraction study of human bone; direct methods of estimating changes in line broadening. Arch. Oral Biol. 12, 73.

GEE, A. \& DerTz, V. R. (1955). Pyrophosphate formation upon ignition of precipitated basic calcium phosphates. J. Am. chem. Soc. 77, 2961.

Herman, H. \& Dallemagne, M. J. (1961). The main mineral constituent of bone and teeth. Arch. Oral Biol. 5, 137.

Herman, H., Francois, P. \& Fabry, C. (1961). Le composé minéral fondamental des tissus calcifiés. I. Présence de groupements acides dans le réseau apatitique des phosphates de calcium synthétiques. Bull. Soc. Chem. 43, 629.

Hill, W. L., Faust, G. T. \& ReYnolds, D. S. (1944). The binary system $\mathrm{P}_{2} \mathrm{O}_{5}-2 \mathrm{CaO} \cdot \mathrm{P}_{2} \mathrm{O}_{5} . A m . J$. Sci. 242, 457.

Howell, A., Jun., Murphy, W. C. III, Paul, F. \& Stephan, R. M. (1959). Oral strains of Actinomyces. J. Bact. 78, 82.

KüHL, G. \& NeberGall, W. H. (1963). Hydrogenphosphat- und Carbonatapatite. Z. anorg. Chem. 324, 313.

Pine, L. \& Overman, J. R. (1963). Determination of the structure and composition of the "sulphur granules' of Actinomyces bovis. J. gen. Microbiol. 32, 209.

Pine, L., Howell, A., Jun. \& WATSON, S. J. (1960). Studies of the morphological, physiological and biochemical characters of Actinomyces bovis. J. gen. Microbiol. 23, 403.

Posner, A. S., EANes, E. D., HARPer, R. A. \& Zipkin, I. (1963). X-ray diffraction analysis of the effect of fluoride on human bone apatite. Arch. oral Biol. 8, 549.

Rizzo, A. A., ScotT, D. B. \& Bladen, H. A. (1963). Calcification of oral bacteria. Ann. N.Y. Acad. Sci. 109, 14.

Rizzo, A. A., Martin, G. R., Scott, D. B. \& Mergenhagen, S. E. (1962). Mineralization of bacteria. Science 135, 439.

Rowles, S. L. (1964). Tooth Enamel, Proceedings of An International Symposium on the Composition, Properties and Fundamental Structure of Tooth Enamel. Ed. by M. J. Stack and R. W. Fearnhead. Bristol: John Wright and Sons, Ltd.

ThomAs, R. S. (1964). Ultrastructural localization of mineral matter in bacterial spores by microincineration. J. Cell Biol. 23, 113.

THOMPson, L. (1950). Isolation and comparison of Actinomyces from human and bovine infections. Proc. Mayo Clin. 25, 81.

Thompson, L. \& LovesTedT, S. A. (1951). An actinomyces-like organism obtained from the human mouth. Proc. Mayo Clin. 26, 169.

Trautz, O. R., Fessenden, E. \& Newton, M. G. (1954). Magnesium whitlockite in ashed dental tissue-an identification by X-ray diffraction. J. dent. Res. 33, 687.

WinAND, L. (1961). Étude physico-chimique du phosphate tricalcique hydraté et de l'hydroxylapatite. Ann. Chim. 6, 941.

WRIGHT, J. H. (1905). The biology of the microorganisms of actinomycosis. J. med. Res. 13, 349. 